\title{
Prototype of the Strategy for the Development of HR Competencies in the State Civil Service in Barru Regency
}

\author{
Andi Rahmatiah Rasyid \\ Ilmu Administrasi Negara, Universitas Pepabri Makassar \\ Email: maynamemay@gmail.com
}

(Received: January 20-2019; revised: February 15-2020; published: June 31-2020)

\begin{abstract}
This study aims to develop a Human Resources competency strategy at the Barru Regent's Office. This research specifically focuses on the prototype design of Human Resources Development apparatus strategies that are effectively used by the Barru district government in the development of Human Resources apparatuses in order to perform high. This research uses a phenomenological approach, the main data collection techniques are interviews, observation Data analysis techniques used is a descriptive qualitative data analysis technique. The analysis was conducted after data collection through interviews and direct observation in the field. The results of the study include the development of quantity and quality of Human Resources Apparatus through mapping, Performance and Competency Mapping through internal policy mechanisms with the principles of Manage Human Performance, Maintenance planning, recruitment, career development, rewards, and dismissal, through Evaluation of Development Performance through training and Internal Guidance and External with the principles of Train, educate and Development and Negotioation for Work Conditions, Meeting the needs through recruitment, promotion and Mutation of the Recruit Activity principle.
\end{abstract}

Keywords: Development; Competence; Prototype; Apparatus

\section{INTRODUCTION}

The human element in the organization is an important element in addition to other elements such as the environment, technology and organizational structure (Jamaluddin et al., 2017; Salam \& Rosdiana, 2015; Tadampali et al., 2016). Humans occupy a central position in an organization. Humans have their own strategic action plans (Cahyaningsih, Sensuse \& Noprisson 2017). Human resources can be used in the analysis of organizational sustainability has not been considered sustainably in human resource management has not been widely developed in all branches of human resource management is one reason for failure to identify the factors that affect the sustainability of human resource management in organizations (Tooranloo, Azadi \& Sayyahpoor 2017). Though humans as a complement in the process of an organization to achieve goals and maximum profits. Of course this leaves the value of the essence of the role of humans in an organization. To increase work productivity, the apparatus must increase knowledge, skills and motivation so that work productivity can be obtained optimally (Putra \& Sobandi 2019).

Competency development management according to (Klet 2008) Competency management uses measurements and assessments on the competencies of all employees, to determine the right 
134| Jurnal Ilmiah Ilmu Administrasi Publik: Jurnal Pemikiran dan Penelitian Administrasi Publik Volume 1o Number 1, January - June 2020. Page 133-142

career development plan to achieve company goals through (1) considering competency; (2) identifying gaps between job descriptions and those of competence; (3) analyzing learning gaps; (4) determine important aspects for the development plan to achieve the future competencies needed for the work tasks to be performed; (5) detecting redundancy; (6). achieve awareness of competencies available for the preparation of new tasks and projects. Competence can be related to performance in a cause-and-effect flow model which shows that goals, temperaments, selfconcepts, and knowledge competencies which then predict performance competencies include intentions, actions and final results.

Very fast regional, national and global shifts and changes must be responded by organizations by making strategic changes. In these shifts and changes, the role of humans becomes increasingly strategic because it is the single most active and adaptive resource. The role of human resource management is enhanced so that organizations become more competitive and able to respond to external challenges for their existence and sustainability. The enhancement of the strategic role of human resource management is manifested through recruitment, placement, payroll and compensation policies and career development based on competence. It is important for organizations to carry out job analysis to set the competency standards required for each position at all levels. The competency standards are then used to make decisions in choosing or rejecting, setting and dismissing someone in office or giving awards / punishment to employees. By implementing competency-based human resource management for organizations there will always be reliable human resources available in facing changes and shifts in the globalization era (Artini 2011).

The novelty of this particular problem lies in highlighting the importance of strategic and strategic linking with human resource management practices. This offers new insights in terms of strategic implications on HR development (Ahammad, Glaister \& Gomes 2020). The implementation of human resource development programs through talent management is an organizational initiative. Factors affecting human resource development programs consist of integrity, professional attitude, orientation to serving the community, continuous learning, and teamwork (Rohida \& Akbar 2019).

Efforts to foster and develop apparatus resources are carried out through education and training programs as stated in Act Number 43 of 1999, article 31, Government Regulation (PP) Number 101 of 2000 concerning Training of Civil Servants Position (PNS), PP Number 11 of 2002 concerning Procurement of Civil Servants and Government Regulation Number 54 of 2003 concerning Formation of Civil Servants and Government Regulation Number 13 of 2000. concerning Appointment of Civil Servants in Structural Positions. As a form of human resource development in the scope of government set out in Law Number 5 of 2014 concerning State Civil Apparatus (ASN) that the State Civil Apparatus (ASN) is a form of profession that contains logical consequences namely the importance of principles, basic values, codes of conduct and codes of conduct, and development competency for ASN employees both Civil Servants (PNS) and Government Employees with Work Agreements (PPPK).

In the recruitment and selection process, the competency requirements have been mentioned in detail in accordance with the regulations. In competency development, the principle of competency-based HRM is also carried out with limited, infrastructure constraints, budget support and perceptions from leaders of organizational units and civil servants themselves become 
obstacles in the implementation of competency development programs (Rosiadi, Setiawan \& Moko 2018).

Human Resources need to offer smarter abilities to increase the effectiveness of HR planning. The organization can record the efficiency and effectiveness of good HR planning if Human Resources aligns with the information system strategy and HR strategy. Organizations need to integrate the HR function with other business functions. This study reveals that Human Resources need to offer smarter abilities to improve the effectiveness of HR planning (Nagendra \& Deshpande 2014). The process of human resource management within the scope of government organizations is carried out in the form of recruitment (procurement), maintenance (maintenance) and development (development). Human Resource Management (HRM) for the public sector, as an organization that has a main orientation in terms of providing quality public services to the community that makes the human component a dominant factor.

The development and management of these competency-based human resources in Kabuapten Barru certainly must be realized in the form of integration of competencies in the implementation of the functions of apparatus human resource management starting from recruitment, placement, compensation, development, and dismissal. Barru Regency BKDD Strategic Plan (2017). Placing the main problems faced from the aspects of Apparatus Resources are (1) Lack of skilled and professional staff, (2) Lack of apparatus who masters technology (3) Creativity and innovation of employees who are still lacking (4) Availability of human resources that are not in accordance with organizational needs and (5) Low understanding of basic tasks and functions.

This reality is one of the obstacles for the local government of Barru Regency in implementing the development of competency-based human resources. While in the ideal concept, in order to create good service, create professional human resources, it needs to be supported by increasing the competence of the apparatus. Another fact in Barru District shows that there is a tendency for low levels of apparatus performance, inaccuracies in placing and transferring personnel according to their field of expertise because they are still more dominantly influenced by political intervention in the recruitment and placement of employees.

The purpose of this study is to complement similar research by focusing on a study of HR competency development strategies at the Barru Regent's Office. This research specifically focuses on the design of prototypes of apparatus HR development strategies that are effectively used by the Barru regency in developing HR apparatuses so that they can perform high. The strength of this research is that it focuses on the formulation of a prototype of a competency-based apparatus HR development strategy that is adjusted to the latest policy on developing competencybased ASN.

\section{METHOD}

This study uses a phenomenological approach, the main data collection techniques are (1) in-depth interviews to obtain information directly by asking questions to key informants and ordinary informants, (2) observation to see or observe changes in the phenomenon social which can then be assessed on these changes. The data source of this study was netted from primary data sources and secondary data in accordance with the proportion of research objectives. Primary data 
136| Jurnal Ilmiah Ilmu Administrasi Publik: Jurnal Pemikiran dan Penelitian Administrasi Publik Volume 10 Number 1, January - June 2020. Page 133-142

sources were obtained through observation and interviews with key informants (main informants) and ordinary informants. Whereas secondary data sources were obtained through the study and analysis of various policy documents, policy processes and the implementation of HR management policies at the research locus. The technique of collecting data through observation is done by directly observing the management activities of the apparatus HR development in Barru Regency, and (3) The technique of collecting data through documentation is data collection using instruments in the form of documents, records, photographs, as well as reports that support research. The main instrument of qualitative research is the researcher itself as the main tool for collecting data to make it easier to make adjustments to the facts in the field. The data analysis technique used is qualitative descriptive data analysis technique. The analysis was conducted after data collection through interviews and direct observation in the field.

\section{RESULT AND DISCUSSION}

\section{Results}

The prototype component of the competency-based ASN development strategy was obtained from the results of data analysis in the form of interviews and documentation studies related to the ASN development policy that its implementation needs to be supported by planning and strategy that can cover the overall effort to improve human resource capabilities in the Barru Regency government organization. In this research, it is known that there is still a need to formulate background and strategic issues regarding the management and management of the state civil apparatus consisting of civil servants and PPPK. The strategic issues that were developed certainly were rationalized based on the main problems faced at the City Government level, including various challenges that must be faced in the future.

The determination of the objectives and direction of the policy in the formulation of the HR development strategy design must cover all aspects that can enable mechanisms and systems to occur. Improvement of human resources is the process of improving human quality so that it can turn into productive labor. The desired quality of human resources, especially in long-term development is able to carry out national development that is innovative and creative, productive and with a high spirit and discipline. Structural Hirearki Training is the training needed to maintain the continuity of the development of Government Employee Apparatus to improve the ability of the same position, or the transfer of equal positions and preparation for those who will be promoted. The same level or higher position. the whole system must consist of structural values (structural alignment), culture (cultural alignment), performance (performance alignment), environment (environment alignment), fitness (fitness) and consensus, organizational goals and objectives, organizational strategy, HR strategy, HRM systems, HRM strategic and HRM outcomes and organizations, resource support (financial), and stakeholders (especially external stakeholders).

Implementation of this human resource development model requires standard processes and mechanisms that begin from the recruitment and selection stages based on organizational competencies and needs or based on the interests of the organization's redeploy. Besides that, it still considers several core determinations that also influence such as the availability of human resources / employees and also financial and other facilities and infrastructure. The prototype 
design of the ASN development strategy began by considering the real conditions of the implementation of the ASN development policy that had been imposed on the Barru District Government (Focus 1) and considering several internal and external factors that influenced the ASN development policy in Barru District (Focus 2). The findings in these two focuses were then consulted with the findings in focus 3 which gave birth to the conceptual foundation of composing a comet based ASN development strategy scheme.

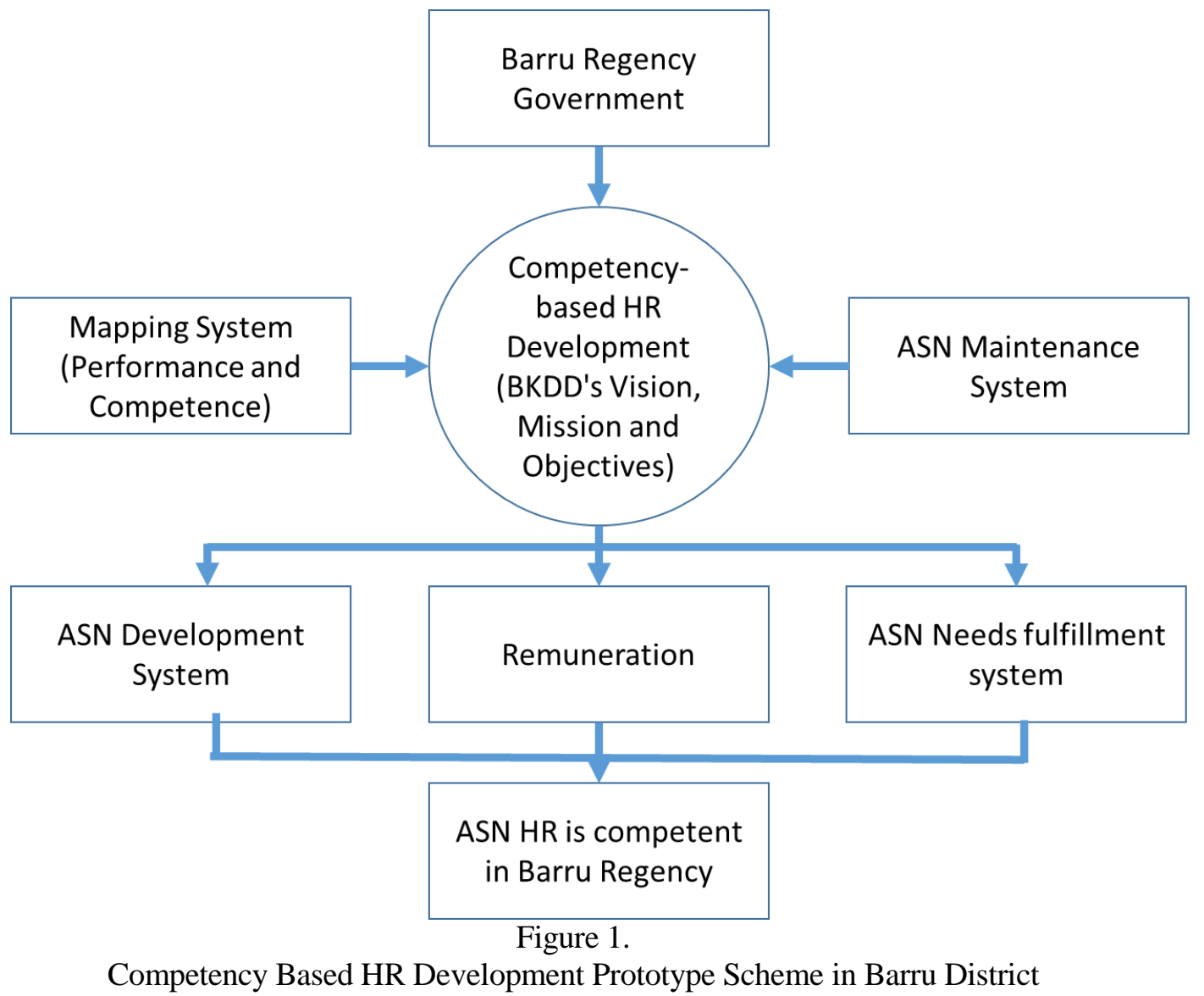

\section{Discussion}

The HR Development Strategy of the apparatus in the prototype mentioned above must meet several basic elements and mechanisms that are oriented to the fulfillment of the apparatus competency. Based on the performance and competency mapping that has been carried out by the Barru District Government, a preparation of the ASN development plan which includes the ASN development plan, plans to meet the needs of the ASN both strength and quality, and the ASN maintenance plan. The details can be stated as follows:

First; The HR Development of the Apparatus is carried out through the formulation and assessment of the vision and mission of the Barru Regency BKDD. The results of the formulation 
138 Jurnal Ilmiah Ilmu Administrasi Publik: Jurnal Pemikiran dan Penelitian Administrasi Publik Volume 10 Number 1, January - June 2020. Page 133-142

and assessment of vision and mission become the basis for the implementation of ASN mapping both related to the quantity and quality of ASN. In the perspective of this study, the mapping should also be focused on mapping ASN competencies to find out the difference between the availability of ASN competencies and the needs of the Barru Regency government organization.

Second; ASN Performance and Competency Mapping System. This process is carried out by adhering to the principles of Manage Human Performance, Implementation of HR performance management, in Barru District carried out to determine various individual targets, monitoring progress and development based on predetermined targets and identifying the needs of training, development, and education in response to the results performance appraisal before determining actions in the form of rewards and discipline actions determined through the BKD internal policy mechanism.

Third; ASN Maintenance System, through Performance Evaluation and Policy. Implementation of the ASN maintenance system as a process of Control Human Resources, Reward and Discipline. The implementation of Human Control Control is carried out in the development of competency-based HRM based on Law Number 5 of 2014 concerning State Civil Apparatus (ASN Law). This application includes planning, recruitment, career development, rewards, and termination / retirement. HR planning to meet employee needs that meet the competency prerequisites compiled starting from Requirement Planning, Arrangement of Number, Position, Procurement and distribution of ASN; Audit or Assessment, Career Development Planning, Career Patterns, ASN Promotions and Mutations; including how to build Integrity and Discipline. Although not entirely based on competence and performance but some are still referring to Law Number 43 of 1999 concerning amendment to Law Number 8 of 1974 concerning the Personnel Principle (Personnel Law).

Fourth; ASN Development System through internal and external training and guidance. The implementation of this system is based on the principles of Train, educate and Development and Negotioation for Work Conditions. The Barru Regency Government conducts train, educate, develop, which is activities aimed at upgrading the capabilities of all existing human resources according to the needs of the organization. This activity is carried out in the form of functional training and tiered leadership training, for example, technical training and training specifically for government leadership to improve the competency of the apparatus and especially the development of ASN character which is entirely carried out based on competence.

The type and functional level for each position are determined by the Institutional Position Board of Trustees of the SKPD. For the fulfillment of position positions with the fulfillment of competence in training, it is adjusted to the qualifications of innovative abilities to foster excellent service orientation. Another strategy implemented in order to upgrade the capabilities of the HR human resources is to modify and create new and innovative ways of working in order to create high performance in each SKPD.

Fulfillment of HR needs is carried out through training, transfer and promotion mechanisms to place employees according to their competencies. This step is a form of negotiation for working conditions, namely activities that are directed to meet HR needs and achieve organizational goals. Competency development, carried out based on PP Number 11 Year 2017 Article 162 Career development, competency development, career patterns, mutations, and promotions are civil servant career management that must be carried out by applying the principles of the Merit 
System. The implementation of managerial competence development through training channels is carried out through structural training consisting of: (1) middle leadership; (2) pratama leadership; (3) administrator leadership; and (4) supervisory leadership.

Fifth; System to fulfill ASN needs through recruitment, promotion and transfer activities. In this section implemented by adhering to the principle of Recruit Activity by considering the position of HR in line with the needs of the organization both from inside and outside sources to obtain the right HR. This mechanism is an effort to select HR to meet the principles of the right people with a selection mechanism based on competency indicators for certain administrator, supervisory and functional positions to select employees who meet the four competencies described in accordance with BAKN.

The selection is based on Law Number 5 of 2014 concerning State Civil Apparatus (ASN). In lieu of Law No. 43 of 1999. This reference is expected by the government of Barru Regency to realize the governance of the state civil apparatus as a profession that has the obligation to manage and develop itself and to account for its performance and to apply the principle of merit in the implementation of the management of the State civil apparatus.

The implementation of the recruitment principle is included in the HRM planning document, although it is not yet specific to potential employee-based development planning. The HRM Planning Document contains (1) employee recruitment based on calculation of needs (2) certification based on Government Regulation Number 18 of 2016 concerning Regional Apparatuses that, every leader of regional apparatus must have government competence as evidenced by certification held by the Institute for Certification of Domestic Government Administrators (LSP-PDN) and (3) employee competency development through education and training.

Employee Recruitment Implementation in Barru Regency is measured through competency tests to measure technical competence, personality competence, and managerial competence to fill certain specified formations. Determination of functional positions must be supported by adequate professional competence so that the policy of Requirement Planning, Arrangement of Number, Position, Procurement and distribution of ASNs must still be arranged properly.

The Planning Aspect is carried out by the mechanism of controlling and monitoring HR planning in Barru Regency in the activities of (1) recruitment and placement of employees, (2) placement of ASN in Supervisory, Administrator, and High Leadership positions, (3) monitoring employee career patterns to place ASN in position in accordance with its competence. The assessment mechanism is carried out for developing career promotion and employee mutations based on Government Regulation Number 41 of 2007 or Law Number 23 of 2014 concerning Regional Government even though it has not been integrated with the development of career patterns.

The development of HRM in Barru Regency is carried out by basing all policies on the vision, mission and goals of the Barru district government. In HRM planning, it is necessary to map the ASN according to its competencies, in addition to mapping the performance and competencies of each ASN. Based on this mapping, the local government of Barru district can conduct a reform of human resources of the apparatus based on their competence. According Sedarmayanti (2001) states that the reformulation of the human resources of the apparatus to build government bureaucracy in order to increase the capacity of the apparatus must continue to be pursued by disciplined application of competence with professionalism and work culture, so that 
140| Jurnal Ilmiah Ilmu Administrasi Publik: Jurnal Pemikiran dan Penelitian Administrasi Publik Volume 10 Number 1, January - June 2020. Page 133-142

it has high technical abilities which at a certain level are also accompanied by great managerial in everything a culture of hard work and high achievement.

The fundamental thing that was also noted was the availability of ASN with qualifications in accordance with local government needs. This requires a recruitment, promotion and transfer process in accordance with the competencies of the apparatus. Therefore, if in real conditions the needs of ASN cannot be fulfilled, then the development of ASN can be done through training and guidance, leadership training and technical training, as well as other formal education tailored to the competencies required by the organization. Measurement of HR capabilities within the Oronomi framework needs to be done as a basis for determining recruitment, placement, transfer and employee workload activities based on their competencies. strategic steps that need to be developed by the local government in the efforts to reform the bureaucracy in managing HR Apparatus. (Fathya 2019)

Related to the development of civil servant capacity, local governments also regularly and periodically involve their employees to attend education and training with the support of their human resource capacity development budget. In addition, in order to find out what training and training are needed to facilitate the implementation of the tasks and principal of the organization, a Training Needs Analysis (AKD / TNA) has also been carried out so that all civil service capacity development needs can be mapped and met according to priority needs.

\section{CONCLUSION}

The prototype of the ASN development strategy with systems and standard mechanisms of operational processes and support processes includes (1) Development of quantity and quality of Apparatus HR through mapping based on the vision and mission of the District BKDD (2) Mapping of ASN Performance and Competence through mechanisms internal policy with the principle of Manage Human Performance, (3) Maintenance of ASN in planning, recruitment, career development, rewards, and termination / retirement activities, through Performance Evaluation and Policy with the principles of Control Human Resources, and Reward and Discipline, (4) ASN Development through internal and external training and guidance with the principles of Train, educate and Development and Negotiations for Work Conditions based on rank and position to upgrade functional and structural HR capabilities, (5) Fulfillment of ASN needs through recruitment, promotion and mutation with the principle of Recruit Activity with Recruit Activity principles with consider an HR position that is in line with the needs of the organization with the principle of the right people with a selection mechanism based on competency indicators for certain administrator, supervisory and functional positions to select employees who meet the four potential descriptions in accordance with the elaboration of BAKN. 


\section{REFERENCES}

Artini, Y. D. (2011). Manajemen Sumber Daya Manusia (MSDM) Berbasis Kompetensi sebagai Strategi Membangun Organisasi Kompetitif. EFISIENSI-Kajian Ilmu Administrasi, 11(2).

Ahammad, M. F., Glaister, K. W., \& Gomes, E. (2020). Strategic agility and human resource management. Human Resource Management Review, 30(1), 100700.

Cahyaningsih, E., Sensuse, D. I., \& Noprisson, H. (2017). Multi Methods for Knowledge Management Strategy Roadmap of Government Human Capital Management. Procedia Computer Science, 124, 496-503.

Fathya, V. N. (2019). Reformasi Manajemen SDM Aparatur di Indonesia. GOVERNMENT: Jurnal Ilmu Pemerintahan, 10(1), 49-56.

Jamaluddin, J., Salam, R., Yunus, H., \& Akib, H. (2017). Pengaruh budaya organisasi terhadap kinerja pegawai pada dinas pendidikan provinsi sulawesi selatan. Jurnal Ad'ministrare, $4(1), 25-34$.

Klett, Fanny. The Design of a Sustainable Competency-Based Human Resources Management : A Holistic Approach. An International Journal. Knowledge Management \& E-Learning:, Vol.2, No.3. p.278-292

Nagendra, A., \& Deshpande, M. (2014). Human Resource Information Systems (HRIS) in HR planning and development in mid to large sized organizations. Procedia-Social and Behavioral Sciences, 133, 61-67.

Peraturan Menteri Dalam Negeri Nomor 54 tahun 2010 tentang Pelaksanaan Peraturan Pemerintah Nomor 8 Tahun 2008 tentang Tahapan, Tata Cara Renstra Badan Kepegawaian Daerah Kab. Barru Tahun 2010-2015

Peraturan Daerah Kabupaten Barru Nomor 6 Tahun 2010 tentang Rencana Pembangunan Jangka Panjang Daerah Kabupaten Barru Tahun 2005-2025

Putra, Y. D., \& Sobandi, A. (2019). Pengembangan sumber daya manusia sebagai faktor yang mempengaruhi produktivitas kerja. Jurnal Pendidikan Manajemen Perkantoran (JPManper), 4(1), 127-133.

Rohida, L., \& Akbar, I. (2019, October). Analysis of Human Resource Development Programs Through Talent Management in Padjadjaran University. In 2019 International Conference on Organizational Innovation (ICOI 19). Atlantis Press.

Rosiadi, A., Setiawan, M., \& Moko, W. (2018). Praktek Manajemen Sumber Daya Manusia Berbasis Kompetensi pada Organisasi Sektor Publik. Jurnal Manajemen Dan Kewirausahaan, 6(2), 156.

Tooranloo, H. S., Azadi, M. H., \& Sayyahpoor, A. (2017). Analyzing factors affecting implementation success of sustainable human resource management (SHRM) using a hybrid approach of FAHP and Type-2 fuzzy DEMATEL. Journal of cleaner production, $162,1252-1265$.

Salam, R., \& Rosdiana. (2015). Penerapan Fungsi Administrasi Perkantoran Modern berbasis Daya Saing Organisasi dalam menyongsong MEA 2015. SEMINAR NASIONAL "Revolusi Mental Dan Kemandirian Bangsa Melalui Pendidikan Ilmu-Ilmu Sosial Dalam Menghadapi MEA 2015” Himpunan Sarjana Pendidikan Ilmu-Ilmu Sosial Indonesia, 1, 186-190. 
142 Jurnal Ilmiah Ilmu Administrasi Publik: Jurnal Pemikiran dan Penelitian Administrasi Publik Volume 1o Number 1, January - June 2020. Page 133-142

Sartika, D., \& Kusumaningrum, M. (2017). Pengembangan Kompetensi Aparatur Sipil Negara di Lingkungan Pemerintah Provinsi Kalimantan Timur. Jurnal Borneo Administrator, 13(2), 131-150.

Sedarmayanti, M., \& Pd, M. (2001). Sumber daya manusia dan produktivitas kerja. Bandung: CV. Mandar Maju.

Tadampali, A. C. T., Hadi, A., \& Salam, R. (2016). Pengaruh Iklim Organisasi terhadap Turnover Intention Melalui Kepuasan Kerja sebagai Variabel Intervening pada PT Bank SulSelBar. Jurnal Ilmiah Ilmu Administrasi Publik, 6(2), 35-46.

Undang-Undang Nomor 43 Tahun 1999 tentang Perubahan Atas Undang-Undang Nomor 8 Tahun 1974 tentang Pokok-Pokok Kepegawaian. 